\title{
The Cheatwood Place (41RR181), a Midden Mound along Little Mustang Creek, Red River County, Texas
}

Steve Gaither

Unknown

Timothy K. Perttula

Heritage Research Center, Stephen F. Austin State University

Gary Cheatwood

Follow this and additional works at: https://scholarworks.sfasu.edu/ita

Part of the American Material Culture Commons, Archaeological Anthropology Commons, Environmental Studies Commons, Other American Studies Commons, Other Arts and Humanities Commons, Other History of Art, Architecture, and Archaeology Commons, and the United States History Commons

Tell us how this article helped you.

This Article is brought to you for free and open access by the Center for Regional Heritage Research at SFA ScholarWorks. It has been accepted for inclusion in Index of Texas Archaeology: Open Access Gray Literature from the Lone Star State by an authorized editor of SFA ScholarWorks. For more information, please contact cdsscholarworks@sfasu.edu. 


\section{The Cheatwood Place (41RR181), a Midden Mound along Little Mustang Creek, Red River County, Texas}

\section{Creative Commons License}

\section{(c) (1) \&}

This work is licensed under a Creative Commons Attribution-NonCommercial 4.0 International License 


\title{
The Cheatwood Place (41RR181), a Midden Mound along Little Mustang Creek, Red River County, Texas
}

\author{
Steve Gaither, Timothy K. Perttula, and Gary Cheatwood
}

The Cheatwood Place is a multi-component midden mound located on an upland projection at the confluence of Christopher Branch and Little Mustang Creek, about 1.5 kilometers north of the Sulphur River. The site has thick midden deposits with excellent faunal and shell preservation, and promises to contribute important information on several periods of Sulphur River prehistory. The archaeological record in this part of the Sulphur River basin is not well known at present (Perttula and Nathan 1989; Peter et al. 1990).

Investigations at the Cheatwood Place site have been limited to surface collections, and the excavation by Cheatwood of a single $1 \times 1$ meter test unit in the midden mound. Vertical provenience was not noted in the test unit, the matrix of which was screened through $1 / 4$ inch mesh, except that the midden was approximately 60 to $90 \mathrm{~cm}$ in thickness with artifacts throughout the deposit.

A total of 845 artifacts have been recovered from the site to date. The assemblage includes 347 pieces of lithic debitage, eight cores, five biface fragments and blank/preforms, five projectile points, 17 unifacial and retouched tools, two pitted stone/hammerstones, 336 fire-cracked rocks and cobbles, 93 ceramic sherds, and 32 pieces of burned clay and daub.

Of the 93 sherds, 17 were decorated (including three rim sherds) and the other 76 were plain (including four rim sherds). The sherds were tabulated by temper: (a) grog (15 sherds $/ 16.1 \%$ of the total); (b) grit (2 sherds/2.1\%); (c) grog and grit (24 sherds/25.8\%); (d) grog and bone (10 sherds/10.8\%); (e) grit and bone (1 sherd/1.1\%); (f) grog, grit, and bone ( 38 sherds $/ 40.9 \%)$; $(\mathrm{g})$ grit and shell $(1$ sherd/1.1\%); and $(\mathrm{h})$ grog and carbonaceous material ( 2 sherds $/ 2.1 \%)$. The grog-grit-bone- combination has the largest representation in the Cheatwood Place assemblage.

These temper categories were subdivided into coarse and fine-tempered sherds to further characterize the ceramic assemblage (cf. Schambach and Miller 1984; Miller 1986; Perttula 1988). This was determined by a visual inspection of the apparent density of the temper in the paste. Fine-tempered sherds include those determined to have 10 percent or less temper by volume; coarse-tempered sherds have 30 percent or more by paste volume. Those few sherds falling between were classified into one of the groups by assessing the size of the individual particles of temper, and the overall homogeneity of the paste and temper.

The coarse-tempered sherds represent 68.8 percent of the assemblage ( 64 sherds); 17.2 percent of these sherds were decorated. The 29 fine-tempered sherds represent 31.2 percent of the collection, but 24.1 percent of this group had been decorated.

The types of decorative techniques identified in the coarse-tempered sherds are predominantly "wet" methods of decoration; that is, the decoration was applied while the clay was still in a plastic stage. Included are two incised, one trailed, three punctated, and one appliqued sherd. Four engraved sherds, a"dry" decorative method that was applied after the clay had reached the leather-hard stage, were also classified as coarse-tempered. The fine tempered sherds were predominantly "dry" decorated (two engraved and three redslipped), although one punctated and one brushed/incised sherd represent "wet" decorated sherds among the fine-tempered group. 
To classify the decorated ceramics from the Cheatwood Place site, the sherds have been divided into ten decorative elements in the manner employed by Miller (1986) in his analysis of a ceramic assemblage from a Caddoan mound site on the Sulphur River in Miller County, Arkansas. The decorative elements are as follows:

Element 1 (Figure 1a): Large triangular punctates on the body of the vessel. Element 2 (Not illustrated): Small triangular punctates placed on the body of the
vessel.

Element 3 (Figure 1b): Horizontal brushing and fingernail punctations on the rim and body of the vessel.

Element 4 (Figure 1c, d): Horizontal incised lines on the vessel rim (carinated bowl).

Element 5 (Figure 1e): Parallel engraved lines with an engraved pendant triangle, The engraved design is on the vessel rim.

Element 6 (Figure 1f): Widely-spaced horizontally engraved lines on the vessel body and rim.

Element 7 (Figure 1g): Curvilinear engraved lines on the vessel rim.

Element 8 (Figure 1h): Trailed lines and brushing on the body of the vessel.

Element 9 (Figure 1i): Parallel applique strips on the vessel body; and

Element 10 (Figure 1j): Brushing on the vessel rim, with possible impressed decorations below the brushing on the vessel body.

Decorative elements 1 and 2 are common on a variety of Caddoan utility vessels, and cannot be assigned to a particular ceramic type. Elements 3,8,9, and 10 closely resemble Pease Brushed-Incised (Suhm and Jelks 1962:119-120), which occurs in frequency at several Caddo sites in the middle and lower Sulphur River drainages that are estimated to date between ca. A.D. 1200-1500 (e.g., Miller 1986). Possible typological identifications for decorative element 4 include East Incised, Davis Incised, and Dunkin Incised; the presence of this decorative element on carinated bowls from Cheatwood Place suggests that they most likely can be assigned to Davis Incised and Dunkin Incised (Suhm and Jelks $1962: 35,37)$. The parallel engraved design with engraved pendant triangles is known to occur in the Sanders Engraved type, but given the location of the site, decorative element 5 is identified as Hempstead Engraved (Suhm and Jelks 1962:69 and Plate 35). Decorative element 6 is possibly Hickory Engraved, while the small sherd with the curvilinear engraved design in element 7 is unidentified. The red-slipped pottery from the site may be from Caddo types such as East Incised (Suhm and Jelks 1962:41), Avery Engraved (Suhm and Jelks 1962:1), Sanders Plain, or Ripley Engraved. Red-slipped pottery is not common in Sulphur River Basin ceramic assemblages (see Heartfield, Price and Greene 1982a, 1982b; Miller 1986; Perttula 1988). 

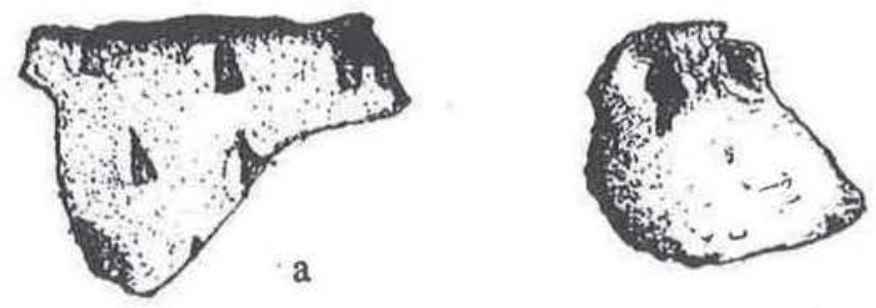

b

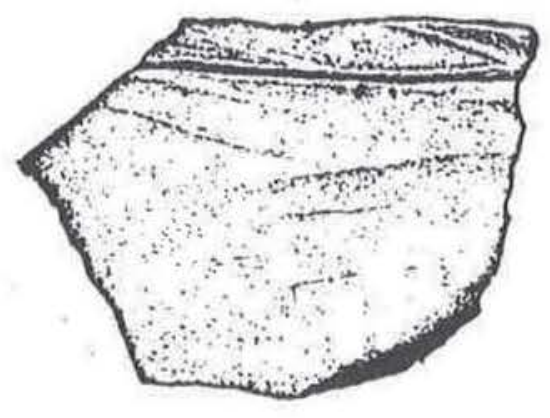

d
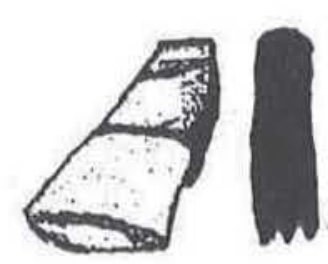

g
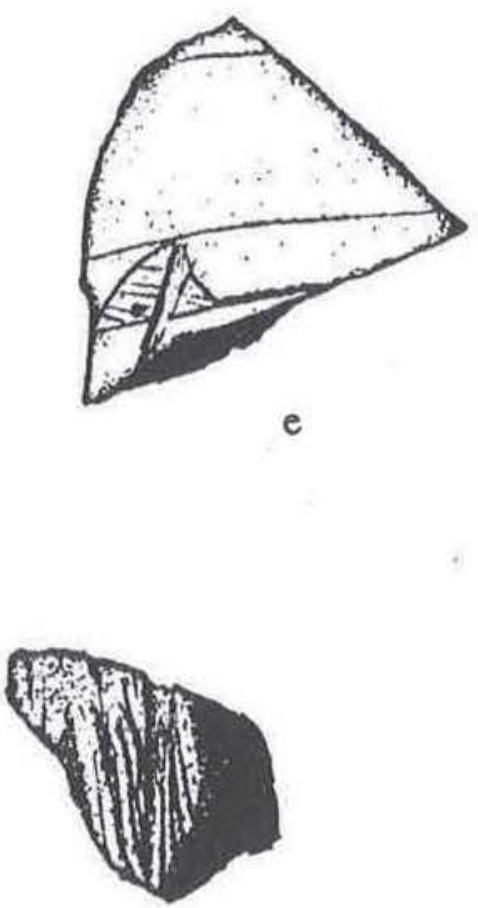

h
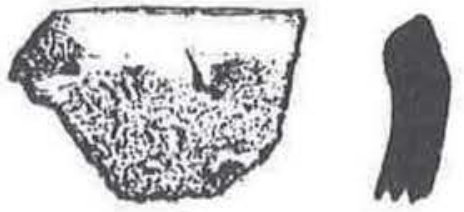
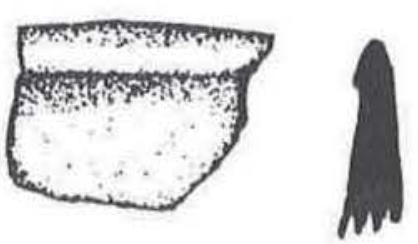

c

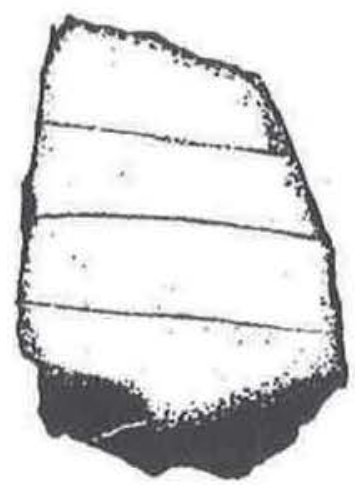

f

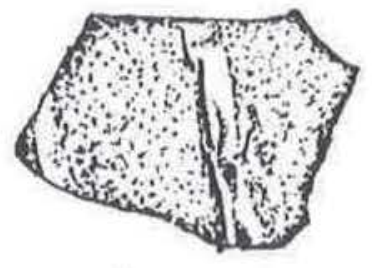

i

j

Figure 1. Decorated Ceramics from the Cheatwood Place Site (41RR181), Red River County, Texas. 
The lithic artifact assemblage primarily consists of lithic debitage and fire-cracked rock. There are small numbers of cores, bifacial tools, groundstone, and a number of expedient unifacial tools and retouched pieces.

Ogallala quartzite, a local resource, dominates the lithic assemblage for debitage and chipped stone tools, accounting for 72.4 percent of the site sample. Other quartzites (those with a coarser texture), petrified wood, jasper, and local cherts account for another 22.7 percent of the assemblage, while lithic raw materials of non-local origin represent only 4.7 percent of the debitage and stone tools. Included in the non-local category are novaculite, chalcedony, a possible Kiamichi Green chert, a possible Frisco chert, and a black siliceous shale. These materials originate in the Ouachita Mountains of Southeast Oklahoma and Southwest Arkansas, but are available as stream gravels in the Red River (see Banks 1990). Although the sample of lithics is small, the percentage of non-local cherts is generally comparable to other known sites in the Middle and Upper Sulphur River basin (Perttula 1984, 1988).

Ten artifacts were classified as bifaces. There are three probable thick bifaces (those more than $10 \mathrm{~mm}$ in thickness) which are best interpreted as manufacturing rejects (Perttula 1988). All are on local coarse-grained quartzite (Figure 2a). The thin bifaces are represented by two small fragments, one a possible medial tool section of Ogallala quartzite with an edge beveled from resharpening, and the other an unidentifiable bifacial tool fragment, also manufactured from Ogallala quartzite.

The projectile points and fragments include a probable Gary type stem of jasper (Figure $2 b$ ), a possible dart point stem of Ogallala quartzite, and another stem manufactured from hematite (Figure 2c). The latter may have been resharpened, which caused the breakage. The fourth dart point was manufactured from Ouachita Mountains siliceous shale. It is not typable as only one worked edge remains of the piece. Medial beveling is evident, and the edge has been resharpened for use. The last projectile point was manufactured from Ogallala quartzite; it's thickness and estimated neck width suggests it is a Gary type, variety Camden (Schambach 1982). It has also been resharpened (Figure 2d).

The 17 unifacial and retouched tools are predominanetly manufactured on Ogallala quartzite flakes, but three of the unifacial tools are manufactured on non-local materials: a dark gray chert with white inclusions, a Red River jasper, and novaculite. Unifacial tools include: (a) utilized flakes, without deliberate retouch (Figure 2e, g), along distal and lateral edges (8/47.1 percent); (b) those with heavier edge utilization and possible retouching (Figure 2f) (3/17.6 percent); (c) a denticulate (Figure 2h) (5.9 percent); (d) three end and side scrapers (Figure 2i, $j$ ) (17.6 percent), (e) a graver; and ( $f$ a perforator.

The perforator is predominantly unifacially worked from a primary flake, and has steep bilateral beveling near the tip; the tip is broken (Figure 2k). The graver is also predominantly unifacial, with edge retouching extending approximately $11 \mathrm{~mm}$ bilaterally from the tip. Both tools show definite use polish.

The cores recovered from 41RR181 include three tested cobbles, three core fragments, and two complete cores (Figure 21). Five of these are of Ogallala quartzite, two are of coarse-grained quartizte, and the other one is of jasper. The tested cobbles, as well as a significant amount of flakes having 76 to 100 percent dorsal cortex $(12.1$ percent of the quartzites) indicates that the cobbles were collected and taken to the site area with only minimal reduction at the procurement areas. The whole Ogallala quartzite cobbles are quite small ( both less than five by three $\mathrm{cm}$ ), and may indicate the minimal size selected for possible future reduction. 

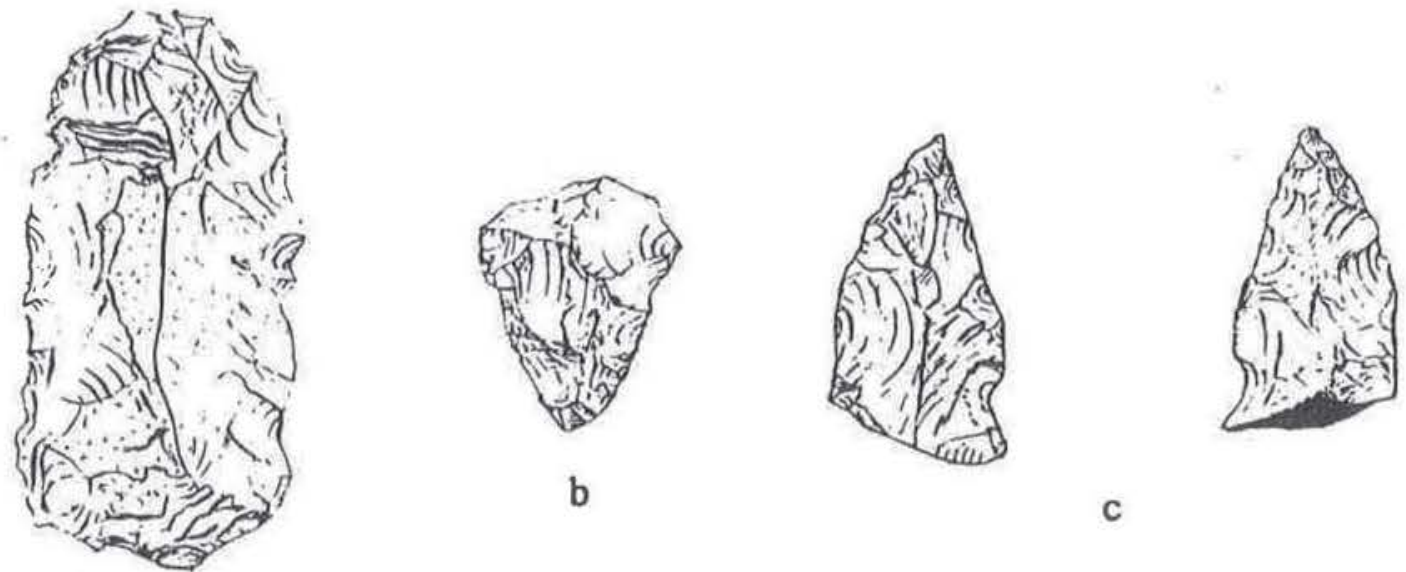

a
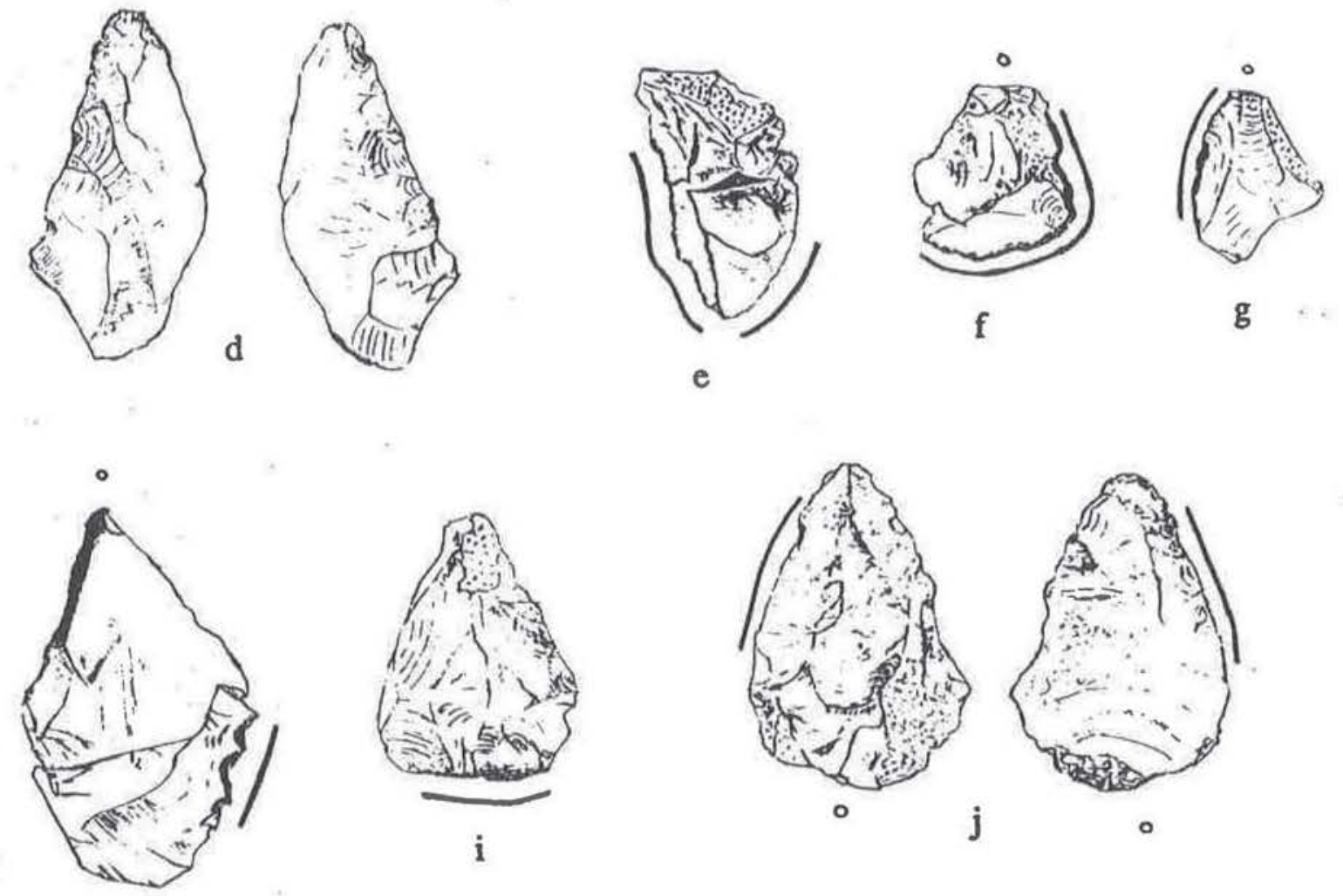

h
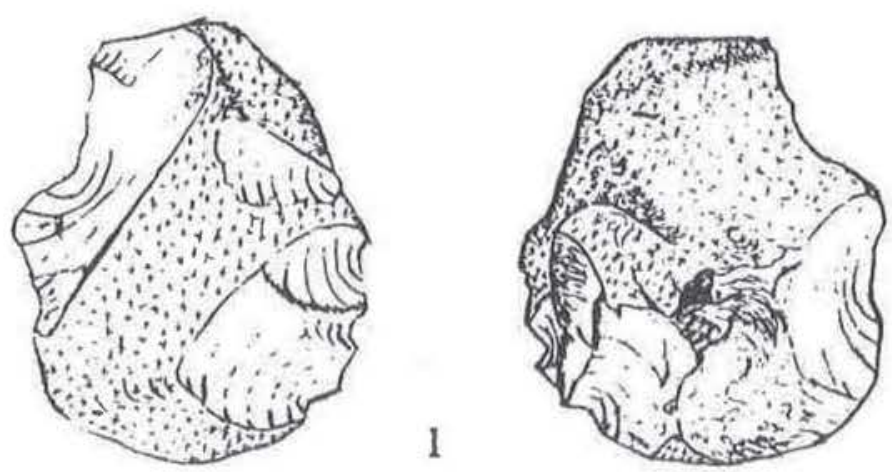

Figure 2. Selected Lithic Tools from the Cheatwood Place Site (41RR181). 
Reduction techniques seem to vary with the coarseness of the lithic material. Those cores with the coarser texture had no apparent platform preparartion, a complete core of Ogallala quartzite that was probably heat-treated showed some evidence of edge preparation by abrading, while the finest-grained Ogallala quartzite cores, also heat-treated, evidence stepped fractures from edge preparation by crushing.

The jasper core is the smallest in the collection; as the core retains dorsal and ventral cortex, and is only $10.4 \mathrm{~mm}$ thick, the original cobble was probably quite small. However, one of the flake scars appears to have a positive percussion bulb indicating that it may be a fragment of a larger tabular cobble.

Two coarse-grained quartzite cobbles show percussive use. The smaller of the two, ovate and thin, has evidence of percussion along one cobble edge, with extensive modification from hammering/pecking at the larger end. No pitting is evident on the cobble faces. The other cobble has pitting on one face, and another area evidences percussive use.

Fire-cracked quartzite rocks and cobbles are abundant in the midden mound, as over 330 have been collected in limited work at the site. Fire-cracked rocks are common byproducts of food preparation activities, and indicate the importance of rocks in cooking actvities. It is possible, however, that the fire-cracked rocks also are by-products of lithic raw material heat-treating actvities, as Banks (1990 personal communication) has noted how important heat-treating is in the Sulphur River Basin to improve the knappability of the local quartzites.

\section{Summary}

The Cheatwood Place midden mound contains an archaeological deposit that dates from at least the last 2000 years. The identified Gary point, and fragments of other contracting stem dart points, probably indicate a Late Archaic and/or an Early Ceramic or Woodland Period occupation (e.g., Schambach 1982; Story 1990). Sites of this time period are common in the area between Mustang Creek and Cuthand Creek in Red River County (Heartfield, Price and Greene, Inc. 1982a, 1982b), and throughout the Sulphur River Basin. Although vertical provenience information is not available from the Cheatwood Place midden mound, it is suspected that a significant portion of the well-preserved midden deposits at the site date to the Late Archaic and/or 'Woodland Period.

A second occupation at Cheatwood Place is represented by the ceramic assemblage; possible decorated sherds of the types Pease Brushed-Incised, Davis Incised, Dunkin Incised, Hempstead Engraved, and Hickory Engraved have been identified among the 17 decorated sherds from the site. Based on the frequency of Pease Brushed-Incised and Hickory Engraved, and comparisons with the dated ceramic assemblage at the Myers Mound, a general temporal range for this occupation is estimated to be ca. A.D. 12001400 , plus or minus 100 years.

Further work is planned for the Cheatwood Place midden mound in 1991. The purpose of the work will be to clarify the vertical and horizontal integrity of the site, and the various occupations preserved in its midden deposits, acquire reliable radiocarbon and thermoluminescence samples for dating purposes, and to recover interpretable samples of faunal and floral remains from the different occupations to discern specific subsistence patterns. If we are successful in acquiring this type of information from the site, archaeologists working in the Sulphur River Basin will be in a better position to address basic issues of cultural change in Northeast Texas. 
References

Banks, Larry D.

1990 From Mountain Peaks to Alligator Stomachs: A Review of Lithic Sources in the Trans-Mississippi South, the Southern Plains, and Adjacent Southwest. Oklahoma Anthropological Society, Memoir \#4.

Heartfield, Price and Greene, Inc.

1982a A Cultural Resources Survey of High Site Probability Locations which will be affected by proposed Levee Construction within Angelina Frams, Red River County, Texas. Heartfield, Price and Greene, Inc., Monroe.

1982b A Cultural Resources Survey of Portions of Harts Bluff Ranch in connection with Corps of Engineers Permit No. SWF-81-TITUS-396. Heartfield, Price and Greene, Inc., Monroe.

Miller, John E. III

1986 The Myers Mound: Salvage Excavations at a Caddo II Site in Southwest Arkansas.

The Arkansas Archeologist 23/24:67-127.

Peter, Duane E., Maynard B. Cliff, James T. Abbott, and Timothy K. Perttula 1990 Research Design for Cultural Resources Investigations at the White Oak Creek Mitigation Area, Bowie, Cass, Morris, and Titus Counties, Texas. Geo-Marine, Inc., Plano.

Perttula, Timothy K.

1984 Patterns of Prehistoric Lithic Raw Material Utilization in the Caddoan Area: Western Gulf Coastal Plain. In Prehistoric Chert Exploitation Studies from the Midcontinent, edited by Brian M. Butler and Ernest E. May, pp. 129-148. Center for Archaeological Investigations, Occasional Paper 2. Southern Illinois University, Carbondale.

1988 The Hurricane Hill Site (41HP106), an Early Ceramic-Caddoan Occupation on the South Sulphur River, Hopkins County, Texas. Draft on file, Institute of Applied Sciences, University of North Texas, Denton.

Schambach, Frank F.

1982 An Outline of Fourche Maline Culture in Southwest Arkansas. In Arkansas Archeology in Review, edited by Neal L. Trubowitz and Marvin D. Jeter, pp. 132197. Arkansas Archeological Survey, Research Series 15. Fayetteville.

Schambach, Frank F. and John E. Miller III

1984 A Description and Analysis of the Ceramics. In Cedar Grove: An Interdisciplinary Investigation of a Late Caddo Framstead in the Red River Valley, edited by Neal L. Trubowitz, pp. 109-170. Arkansas Archeological Survey, Research Series 23. Fayetteville.

Story, Dee Ann

1990 Cultural History of the Native Americans. In The Archeology and Bioarcheolgy of the Gulf Coastal Plain, by Dee Ann Story et al., pp. 163-366. Arkansas Archeological Survey, Research Series No. 38. Fayetteville. 
Suhm, Dee Ann and Edward B. Jelks

1962 Handbook of Texas Archeology: Type Descriptions. Texas Archeological

Society Special Publication No. 1 and Texas Memorial Museum Bulletin No. 4. Austin.

\section{SUBSCRIPTIONS}

Annual subscription rates for the Caddoan Archeology Newsletter are $\$ 10$. Volume II, No. 1 of the newsletter will be distributed to subscribers in March 1991, and subsequent issues will be distributed in July, October, and January 1992.

Back issues are available from the Editor for $\$ 2.50$ per newsletter.

Detach and return this portion with your check subscription

Enclosed is my check for $\$ 10.00$ for a one year

Name

Address

Phone

Please make check payable to : Caddo Archeology/Tim Perttula

Mail subscription form and check to: Timothy K. Perttula, Editor of Caddoan Archeology Newsletter, c/o Texas Historical Commission, P.O. Box 12276, Austin, Texas 78711-2276 